\title{
Investment Property, Cost Model, Fair Value Model and Value Relevance: Evidence From Malaysia
}

\author{
Mohd Halim Kadri ${ }^{1}$, Juyati Mohd Amin ${ }^{1} \&$ Zarina Abu Bakar ${ }^{1}$ \\ ${ }^{1}$ Universiti Teknologi MARA, Johore Branch, Johor, Malaysia \\ Correspondence: Mohamed Halim Kadri, Accounting Faculty, Universiti Teknologi MARA, Johor, Malaysia. E-mail: \\ mhalim@uitm.edu.my
}

Received: May 12, 2020

Accepted: June 20, 2020

Online Published: June 29, 2020

doi:10.5430/ijfr.v11n3p115

URL: https://doi.org/10.5430/ijfr.v11n3p115

\begin{abstract}
The purpose of the study is to investigate the value relevance of investment property of Malaysian listed firms based on cost model and fair value model for measuring their investment properties. Some studies suggested fair value model is more value relevant and some other studies suggested cost model is more value relevant. The sample was selected using a simple random sampling so that all listed firms have equal chance to be selected. A final sample of 108 firm-year from various industries was selected for a period from 2018 to 2019. Equity valuation models developed by Landsman (1986) and Ohlson (1995) were used to test the value relevance of investment property employed by listed firms in Malaysia. The models were used to test the value relevant of pooled sample, fair value sample and cost sample. The results show that firms' investment properties are value relevant regardless whether cost model or fair value model was selected. It was also found that depreciation included in cost model and fair value gain or loss included in fair value model net profits are value relevant. The study implicates that cost model is more value relevant in measuring investment property. The result provides useful insight to standard setter about the effect of selection of fair value model and cost model towards share market value. Standard setters, researchers and academics would benefit from this as prior research in Malaysia suggests that investment properties (in general) are not value relevant even though investment properties of property companies are value relevant.
\end{abstract}

Keywords: investment property, cost model, fair value model, value relevance, Malaysia

\section{Introduction}

In 2008, the Malaysian Accounting Standards Board (MASB) issued a statement about its plan to bring Malaysia to full convergence with International Financial Reporting Standards (IFRS) by 1 January 2012. As part of the convergence, a new IFRS-compliant framework (MFRS Framework) was introduced to be effective on 1 January 2012. Consequently, many IFRS-equivalent reporting standards were issued including MFRS 140 - Investment property (IP) in November 2011. The main impact of adopting the IFRS-equivalent reporting standards by firms Malaysia is that most of assets and liabilities will be stated at fair values and this reflects the firms' true financial position. Therefore, when used, the application of the IFRS-equivalent reporting standards will enhance the qualitative characteristics of the accounting information in terms of relevance.

The MFRS 140 Investment Property is important for accountants, auditors and financial statement users in this regard because it will be the first time which the Malaysian Accounting Standards Board (MASB) had introduced a fair value accounting model for investment properties. The MFRS 140 is mandated to be applied in financial statements beginning on or after 1 January 2012. The MFRS 140 allows firms to choose either the fair value model or the cost model for valuing their IPs, after the initial recognition is made. The consequence from selecting different accounting models is the earnings of fair value model firms will include the gain or loss due to a change in the fair value of the IP while the cost model firm will include depreciation charge for IPs. So the earnings of fair value model firms could be more volatile than those of the cost model firms.

The choice between the two models affects the reported income and net assets value. Supporters of fair value model believe that the disclosed and recognized fair value are informative to investors (Landsman, 2007) and less biased and more accurate measures of selling price than historical cost. Whereas critics of fair value state that fair value reduce reliability (Nellessen and Zuelch, 2010). On the other hand, Muller, Riedl and Selhorn (2008) suggest no different information asymmetry between fair value model and cost model. 
Prior studies show the selection and determinants of selection accounting methods for IP all over the world. Most of Portuguese listed companies adopt cost model (Selas, 2009), 76.7\% of Nigerian firms selected cost model (Isa, 2014), majority of companies in Thailand selected cost model rather than fair value model (Acaranupong, 2017), approximately 50\% of companies in China selected the cost model (Taplin, Yuan, and Brown, 2014) and most of Indonesian listed companies (including real estate companies) selected cost model (Wahyuni, Soepriyanto, Avianti and Naulibasa, 2019). Christensen and Nikolaev (2009) show that real estate companies in UK and German that hold investment property tend to use fair value instead of historical cost (Christensen and Nikolaev, 2009).

About the determinants of selection of accounting choice, Wahyuni et al. (2019) include size, profitability, leverage and growth to be tested as determinants of valuation model selection in Indonesia. However, only growth is significant in determining the model selection. Taplin et al. (2014) suggested company size and leverage to be determinants of selection of valuation model for investment properties in China. However, only size is significant at $10 \%$ level. Isa (2014) suggested that the selection of accounting models is determined by profitability, leverage and size. However the results of the study only found size as the determinants of accounting choice. Acaranupong (2017) found profitability and size to be the determinants of model selection.

Many studies have been conducted on value relevance of investment property. However, prior studies show mix results. Some researchers found Investment properties are value relevant whereas some researchers did not find the same results. Those who support the relevance of investment properties are Acaranupong (2017), Lourenço and Curto (2007), Weijun (2007), So and Smith (2009), Al-Khadash and Khasawneh (2014), Ahmad and Aladwan (2015), Selas (2009) and Zi, Hassan and Embong (2014). While those who found investment properties are not relevant are Ishak, Saringat, Ibrahim and El-Shahat (2011), Abdul Jabar and Mohamed (2015) and Alhusaini and Elshamy (2016).

Current study intends to investigate the situation in Malaysia with the following main objective: The main objective of the study is to investigate the value relevance of investment properties among companies listed in Bursa Malaysia. The study is using secondary data of listed companies. The sample was selected based on simple random sampling of all listed companies in Malaysia based on Sekaran (2006). The study employed descriptive as well as inferential statistics including regression. The study utilised Landsman (1986) and Ohlson (1995) equity valuation models to test the relevance of investment property towards share market price.

\section{Literature Review}

This chapter reviews previous literature related to selection of investment property valuation models, the determinants for selection and value relevance of investment property.

\subsection{Investment Property, Cost Model and Fair Value Model}

MFRS 140 - Investment property was issued by Malaysian Accounting Standards Board (MASB) on 19 November 2011 and applicable for annual period beginning 1 January 2012. The purpose of issuance of MFRS 140 is to differentiate the assets from another category of non-current assets that is property, plant and equipment (PPE) whereby PPE are dealt with by MFRS 116. Investment property is a land or building or part of land or building or both acquired for the purposes of rentals or capital appreciation of both and not for sale in ordinary course of business, for production of goods or service or to be occupied by employees.

An investment property shall be initially measured at cost, including transaction charges. After initial recognition, MFRS140 Investment Property allows companies to choose between the cost model and fair value model. Under the cost model, investment property should be measured in accordance with MFRS 116 Property, Plant and Equipment. Under the fair value model, any investment property should be measured at fair value, with changes being recognised as gains or losses. Even if an entity measures an investment property under the cost model, it is still required by MFRS 140 to disclose the fair value of such investment property in the notes to the financial statements (https://masb.org.my).

\subsection{Determinants of Model Selection}

Wahyuni, Soepriyanto, Avianti and Naulibasa (2019) include size, profitability, leverage and growth to be tested as determinants of valuation model selection in Indonesia. However, only growth is significant in determining the model selection. Taplin et al. (2014) suggested company size and leverage to be determinants of selection of valuation model for investment properties in China. However, only size is significant at $10 \%$ level.

Isa (2014) suggested that the selection of accounting models is determined by profitability, leverage and size. However the results of the study only found size as the determinants of accounting choice. Acaranupong (2017) 
found profitability and size to be the determinants of model selection. Based on the above studies, current study will include profitability, size, leverage and growth as the prospects of determinants of accounting choice for investment properties in Malaysia.

\subsection{Value Relevance of Investment Property}

Accounting numbers - assets, liabilities, earnings and equity are supposed to be value relevant (Ohlson, 1995; Landsman, 1986; Ibrahim, Danila, Yusoff, and Yatim, 2002). A study by Ball (2016) stated that fair value accounting provides accurate and comprehensive financial statement information.

A few studies have been conducted all over the world about the relevance of investment property towards market value of shares. The studies can be divided into two: first studies that found investment properties are value relevant and second, studies that found investment properties are not value relevant. Israeli (2015) examined 86 real estate firms in France, Germany, Italy and Spain in 2011. His findings suggested that the recognition using fair value model versus disclosure using historical cost model are equally relevant for future financial outcomes and investors weight disclosed information less heavily in determining a firm's value.

A recent study by Acaranupong (2017) on Thailand sample from 2011 to 2012 found that Investment Properties of Thailand companies are value relevant. However, investment properties valued based on cost model is more value relevant than property valued based on fair value. Lawrence and Curto (2007) that studied four countries in European Union also found both Investment Properties measured at cost and at fair value are value relevant. Two studies about Hong Kong found similar results. Weijun (2007) that studied real estate companies in Hong Kong found fair value of investment property is relevant to the investors when they are making economic decisions related to the respective company. While So and Smith (2009) that studied listed property companies in Hong Kong during 2004-2006 found a significantly higher market price reaction and returns associations when fair value changes are reported in income statements.

Two studies from Jordan Stock Exchange also found similar results. Al-Khadash and Khasawneh (2014) covered Jordanian companies listed on Amman Stock Exchange for the period of 2002 - 2009 found unrealized gains and losses affect the net income and the results of cross-sectional regression indicate that net income and book values jointly and individually are positively and significantly related to stock prices. Alhaj Ahmad and Aladwan (2015) investigated 41 real estate companies from 2008 to 2011. They found the unrealized gain \& losses inclusion in owners' equity increases the explanatory power of the firm's market value model of real estate companies. Using a sample of Portuguese listed companies in the period after the mandatory IFRS adoption, Selas (2009) results indicated that in Portugal, investors price shares differently when companies choose either the cost model or the fair value model.

There is only one research so far that found a negative effect of adopting investment property standard. Alhusaini and Elshamy (2016) examined the value relevance of unrealised gains and losses of IP reported in the income statement in explaining stock prices for real estate companies listed in Kuwait stock exchange. They found that gains and losses recognised under IAS 40 decreases the explanatory power of the valuation model and decreases the incremental explanatory power of earnings.

Elsiefy and ElGammal (2017) examine the effect of the use of the fair value model under IAS 40 of accounting for an investment property on the fundamental analysis of a real estate developer company listed in Qatar Exchange. The results show that the choice of fair value model has a small impact on balance sheet items, while the effect on income statement is significant which shows net income has the highest impact. However it was stated this impact has not had any impact on the company's share price. Israeli (2015) also found strong evidence that equity investors place small valuation weights on recognised and disclosed amount of fair value.

\subsection{Value Relevance of Investment Property in Malaysia}

In Malaysia, there were three studies investigating about the value relevance of investment property. The first study by Ishak, Saringat, Ibrahim and El Shahat (2011) investigated the value relevance of investment property of Malaysian companies and found that investment properties are not value relevant. Probably, using a dataset from 2009 to 2011 could be too early to detect the value relevance of investment property in Malaysia as companies are only required to adopt MFRS 140 starting from 1 January 2012.

In another study, Abdul Jabbar and Mohamed (2015) examined the value relevance of fair value accounting under the adoption of MFRS 140 Investment Property in Malaysia based on 200 Malaysian public listed companies from various industries in 2006 to 2011. Their study found out that the disclosure of fair value of investment property for all the six years does not influence investors in setting the share price of the companies. Their results suggested that 
the fair value of investment property has no significant relationship with share price for all the periods (2006-2011). Another study by Zi, Hassan and Embong (2015) used data from real estate investment trust (REIT). The study found that Investment properties of those trusts companies are value relevant. Studies covering a period of 2009-2011 (Ishak et al., 2011), 2006-2011 (Abdul Jabbar and Mohamed, 2015) and focus only on REAT (Zi et al., 2014) may not generalise the value relevance of investment property of all sectors and more recent years of companies listed on Bursa Malaysia. Therefore, current study investigates the level of selections of cost model and fair value model and value relevance of those models towards market value of Malaysian companies listed on Bursa Malaysia in a more recent period (2018-2019).

Hypotheses

$\mathrm{H}_{\mathrm{A}} 1$ : Investment properties are value relevant

$\mathrm{H}_{\mathrm{A}}$ 2: Investment properties measured based on cost model are value relevant

$\mathrm{H}_{\mathrm{A}} 3$ : Investment properties measured based on fair value model are value relevant.

\section{Methodology}

\subsection{Research Design}

In a value relevance study, a market research approach is applied. The study utilised value relevance model found by Landsman (1968) and Ohlson (1995) to test the value relevance of investment property of Malaysian listed companies.

\subsection{Sampling Techniques}

Simple random sampling was used so that each listed company will have equal chance of being selected as sample. The sample was taken on 18 June 2019 when the population size was 794 firms. Using the excel software a sample of 110 firms was selected. However, 4 numbers came out twice. So, only 106 firms were selected as sample.

Table 1. Sample selection

\begin{tabular}{|c|c|c|c|c|c|c|}
\hline \multicolumn{7}{|c|}{ Firm No. in Bursa Malaysia } \\
\hline 1. & 1 & 19. 103 & 37. 228 & 55. 381 & 73.546 & 91. 647 \\
\hline 2. & 7 & 20. 126 & 38. 231 & 56. 390 & 74. 546 & 92. 652 \\
\hline 3. & 10 & 21. 135 & 39. 244 & 57. 391 & 75. 562 & 93. 663 \\
\hline 4. & 12 & 22. 138 & 40. 247 & 58. 395 & 76. 571 & 94. 674 \\
\hline 5. & 16 & 23. 159 & 41. 251 & 59. 427 & 77. 574 & 95. 686 \\
\hline 6. & 17 & 24. 167 & 42. 253 & 60. 439 & 78. 582 & 96. 700 \\
\hline 7. & 18 & 25. 172 & 43. 261 & 61. 454 & 79. 585 & 97. 723 \\
\hline 8. & 28 & 26. 173 & 44. 295 & 62. 462 & 80. 586 & 98. 735 \\
\hline & 30 & 27. 178 & 45. 303 & 63. 463 & 81. 590 & 99. 745 \\
\hline & 34 & 28. 180 & 46. 324 & 64. 477 & 82. 597 & 100. 749 \\
\hline & 37 & 29. 186 & 47. 336 & 65. 496 & 83. 606 & 101.750 \\
\hline & 48 & 30. 193 & 48. 345 & 66. 500 & 84. 610 & 102.759 \\
\hline & 56 & 31. 194 & 49. 347 & 67. 509 & 85. 617 & 103. 769 \\
\hline & 61 & 32. 203 & 50. 355 & 68. 510 & 86. 624 & 104. 770 \\
\hline & 79 & 33. 205 & 51. 361 & 69. 520 & 87. 625 & 105.773 \\
\hline 16. & 81 & 34. 207 & 52. 365 & 70. 526 & 88. 630 & 106. 784 \\
\hline & 93 & 35. 210 & 53. 373 & 71. 542 & 89. 636 & \\
\hline 18. & 99 & 36. 220 & 54. 375 & 72. 543 & 90.638 & \\
\hline
\end{tabular}

According to Tabachnick and Fidell (2013) a sample size that fits the following formula is sufficient:

$$
\mathrm{N}=50+8(\mathrm{IV})
$$

Where, $\mathrm{N}$ is number of sample, IV is independent variable. This study only has 2 independent variables in each model. Therefore, the sufficient sample size $=50+8(2)=66$. As a precaution, in case useful sample become smaller, two years data were gathered. 
Table 2. Final sample based on simple random sampling technique

\begin{tabular}{ll}
\hline Original sample size & 110 \\
\hline Less: number came out twice & $(4)$ \\
\hline Less: Firms with no investment properties & 52 \\
\hline Final sample size & 54 \\
\hline Number of observation (sample X 2) & 108 \\
\hline
\end{tabular}

\subsection{Statistical Models}

The first statistical test is to find the determinants for selection of valuation model for investment property. As mentioned earlier in literature review section, previous studies suggested size, profitability, leverage and growth as possible determinants of selection: So the following model was tested:

$$
\text { MODjt }=\alpha+\beta_{1} \text { SIZEjt }+\beta_{2} \text { PROFjt }+\beta_{3} \text { LEVjt }+\beta_{4} \text { GROWjt }
$$

Where,

MODjt is model selection of firm $\mathrm{j}$ at year $\mathrm{t}$

SIZEjt is the natural log of total asset of firm $\mathrm{j}$ at year $\mathrm{t}$

PROFjt is profitability measured by return on asset of firm $j$ year $t$

LEVjt is leverage measured by total liability divided by total asset of firm $j$ at year $t$

GROWjt is growth measured by market value divided by book value of equity of firm $\mathrm{j}$ at year $\mathrm{t}$

The rest of the statistical procedures used equity valuation models - that is the relationship between market value of equity and book value of equity. So the study selected Landsman (1986) model to be used throughout the study. The basic model is well known as The Balance Sheet Identity model as first mentioned by Landsman in 1986. Among other researchers who have based their work on this model are Kane and Unal (1990), Shevlin (1991), Gopalakrishnan and Sugrue (1993), McCarthy and Schneider (1995), Jennings et al (1996) and Pfeiffer (1998).

Basic Landsman (1986) model:

$$
\text { MVOEjt }=\alpha+\beta_{1} \text { BVOEjt }
$$

Modified model to facilitate the inclusion of investment property:

$$
\text { MVOEjt }=\alpha+\beta_{1} \text { BVENOIPjt }+\beta_{2} \text { IPjt }
$$

Due to the fact that cost model and fair value model selected will also affect the profit after tax of the firms depreciation for cost model and fair value gain or loss for fair value model, Ohlson (1995) was also being employed. Below is the model developed by Ohlson (1995):

$$
\text { MVOEjt }=\alpha+\beta_{1} \text { BVOEjt }+\beta_{2} \mathrm{NPjt}
$$

Where,

MVOEjt is market value of equity of firm $j$ at year $t$

BVOEjt is book value of equity of firm $j$ at year $t$

BVENOIPjt is book value of equity net off investment property of firm $j$ at year $t$

IPjt is investment property of firm $j$ at year $t$

And NPjt is net profit after tax of firm $j$ at year $t$.

\section{Result and Discussion}

\subsection{Descriptive Statistics}

Based on sample selected through simple random sampling, 106 firms are selected. However, 52 of the firms did not own any investment property. Therefore, only 54 firms are eligible to be brought further in the study. It was found that $50 \%$ (27/54) of the companies understudy selected cost model and the other 50\% selected Fair value model. 40\% of small companies selected Fair value model whereas $60 \%$ of small companies selected cost model. $65.5 \%$ of large companies selected fair value model whereas $34.5 \%$ selected cost model. The selection of valuation model by 
Malaysian listed companies is following the trends in China as mentioned by Taplin et al. (2014). The result shows that majority of large firms prefer fair value model whereas majority of small firms prefer cost model. This result answers research question 1 and objective 1 of the study about the extent of selection of cost model and fair value model among listed firms in Malaysia.

Table 3. Descriptive statistics

\begin{tabular}{lccc}
\hline Size & Cost model & Fair value model & Total \\
\hline Small & $18(\mathrm{~N}=36)$ & $12(\mathrm{~N}=24)$ & $30(\mathrm{~N}=60)$ \\
Large & $9(\mathrm{~N}=18)$ & $15(\mathrm{~N}=30)$ & $24(\mathrm{~N}=48)$ \\
\hline Total & $27(\mathrm{~N}=54)$ & $27(\mathrm{~N}=54)$ & $54 \quad \mathrm{~N}=108)$ \\
\hline
\end{tabular}

\subsection{Regression on Determinants of Model Selection}

In order to support the first objective of the study, regression test was performed to identify the factors determining the selection of valuation model. Size, profitability, leverage and growth are regressed against selection of investment property valuation model.

$$
\text { MODjt }=\alpha+\beta_{1} \text { SIZEjt }+\beta_{2} \text { PROFjt }+\beta_{3} \text { LEVjt }+\beta_{4} \text { GROWjt }
$$

The results show that Size, Profitability and Leverage do not determine the selection of valuation model. Instead, selection of IP valuation model is determined by Growth represented by Market-to-Book Value Ratio. Wahyuni et al. (2019) argued that size, profitability and leverage are not the determinants of valuation model selection in Indonesia. Only growth is significant in determining the selection of those models. Taplin et al. (2014) also suggest that size and leverage as not the factor for selection of valuation model in China. Isa (2014) tested profitability, leverage and size but only size was significant. Acaranupong (2017) found profitability and size to be the determinants of model selection while Isa (2014) suggested that the selection of accounting models is determined by profitability, leverage and size. However the results of the study only found size as the determinants of accounting choice. So this study is supporting the result of Wahyuni et al. (2019).

Table 4. Determinants of model selection

\begin{tabular}{lr}
\hline Variables & Coefficient (sig) \\
\hline Constant & $1.5290(.017)$ \\
SIZE & $-.0517(.130)$ \\
PROF & $-.5058(.376)$ \\
LEV & $.0311(.904)$ \\
GROWH & $.0014(.000)$ \\
\hline Two-tailed regression model was utilised. \\
\hline
\end{tabular}

\subsection{Regression Models to Prove That Investment Properties Are Value Relevant}

Objective 2 of the study is to investigate whether investment property are value relevant. $\mathrm{H}_{\mathrm{A}} 1$ states that Investment properties are value relevant - pool sample. The hypothesis was tested using 3 models. In the first regression, the pooled data was used to test model 1 that is the relationship between market value and book value of equity. The result shows that BVOE is significantly related to MVOE at $5 \%$ confidence level with an adjusted $\mathrm{R}^{2}$ of .8644 . It means BVOE has information content and able to explain $86.44 \%$ of the variation in MVOE. In other word, BVOE is value relevant. This result supports the study done by Landsman (1986) that BVOE of equity was value relevant that is able to explain the variation in MVOE.

The second regression model is to find the relationship between MVOE and the BVOE separated into BVENOIP and IP. The result show that BVENOIP and IP are significant at $95 \%$ confidence level with an explanatory power of $86.68 \%\left(\mathrm{R}^{2}=.8668\right)$. It indicates even though BVOE was separated into BVENOIP and IP, they are still significant and able to explain the variation in MVOE separately with a slightly higher explanatory power. It also explains that information content of IP is captured by the market and incorporated as part of the components of MVOE. In other 
word, IP is value relevant. The third regression model tested the relationship of BVOE and NP towards MVOE of pool sample. The result shows BVOE and NP are significant at $95 \%$ confidence level with an adjusted $\mathrm{R}^{2}$ of .9878 and $\mathrm{p}=.000$. Both BVOE and NP are able to explain the variation in MVOE. The inclusion of NP increases the explanation by $12.34 \%(98.78 \%-86.44 \%)$. The result proved that NP is value relevant. The result also support the study by Ohlson (1995).

Table 5. Relationship of BVOE, BVENOIP, IP and IP towards MVOE (Pooled sample)

\begin{tabular}{|c|c|c|c|}
\hline & $\begin{array}{r}\text { Model } 1 \\
\text { Coefficient (Sig) }\end{array}$ & $\begin{array}{r}\text { Model } 2 \\
\text { Coefficient (Sig) }\end{array}$ & $\begin{array}{r}\text { Model } 3 \\
\text { Coefficient (Sig) }\end{array}$ \\
\hline Constant & $-1.79(.002)$ & $-2.40(.000)$ & $-8.92(.000)$ \\
\hline BVOE & $3.69(.000)$ & & $2.01(.000)$ \\
\hline BVENOIP & & $3.60(.000)$ & \\
\hline IP & & $11.47(.000)$ & \\
\hline NP & & & $19.42(.000)$ \\
\hline $\mathrm{N}$ & 108 & 108 & 108 \\
\hline VIF & & 5.142 & \\
\hline F Stat & 683.1 & $349.1(.000)$ & $4348.1(.000)$ \\
\hline $\mathrm{R}^{2}$ & .8657 & .8693 & .9881 \\
\hline Adj. $R^{2}$ & .8644 & .8668 & .9878 \\
\hline
\end{tabular}

\subsection{Regression Models to Prove That Investment Property Valued Using Cost Model Are Value Relevant}

The sample was separated into cost model sample and fair value model to address $\mathrm{H}_{\mathrm{A}} 2$ and $\mathrm{H}_{\mathrm{A}} 3$. Based on model 1, the result show that BVOE is significantly related to MVOE at $5 \%$ confidence level with an adjusted $\mathrm{R}^{2}$ of .9794 . This indicate that BVOE of cost model is able to explain $97.94 \%$ variation in MVOE with a substantially higher percentage (97.94-86.44). It can be concluded that BVOE of cost model sample is value relevant. This result support the study done by Landsman (1986) that BVOE of equity was value relevant that is able to explain the variation in MVOE. Second regression model found that BVENOIP and IP are significant at $95 \%$ confidence level with an explanatory power of $98.26 \%$ (Adj. $\mathrm{R}^{2}=.9826$ ). It indicates that the disaggregated BVENOIP and IP contained significant information that are relevant in explaining the variation in MVOE with a slightly higher explanatory power. It can be concluded that IP is value relevant.

Table 6. Relationship of BVOE, BVENOIP, IP and IP towards MVOE (Cost model)

\begin{tabular}{lrrr}
\hline & $\begin{array}{r}\text { Model 1 } \\
\text { Coefficient (Sig) }\end{array}$ & $\begin{array}{r}\text { Model 2 } \\
\text { Coefficient (Sig) }\end{array}$ & $\begin{array}{r}\text { Model 3 } \\
\text { Coefficient (Sig) }\end{array}$ \\
\hline Constant & $-4.56(.022)$ & $-6.80(.000)$ & $-3.33(.016)$ \\
BVOE & $2.15(.000)$ & & $2.13(.000)$ \\
BVENOIP & & $2.13(.000)$ & \\
IP & & $5.21(.000)$ & $10.26(.000)$ \\
NP & & & 54 \\
N & 54 & 54 & $5162.2(.000)$ \\
F Stat & $2516.1(.000)$ & $1496.0(.000)$ & .9951 \\
$\mathrm{R}^{2}$ & .9798 & .9832 & .9949 \\
Adj. $\mathrm{R}^{2}$ & .9794 & .9826 & \\
\hline Two-tailed regression models were utilised. & & \\
\hline
\end{tabular}

Model 3 show the relationship of BVOE and NP towards MVOE. The result indicates that BVOE and NP are 
significantly related to MVOE. BVOE and NP can explain $99.49 \%$ of the variation in MVOE at $95 \%$ confidence level. The result proved that BVOE and NP of cost model sample are value relevant. It is important to note that NP in this model is representing the depreciation charge on investment property owned by the firms. It has an incremental value relevance of $1.11 \%$ (Adj. $\mathrm{R}^{2}$ arose from .9949 to .9797 ) from Model 1.

\subsection{Regression Model to Prove Investment Property Valued Using Fair Value Model Are Value Relevant}

The result of model 1 shows that BVOE is significantly related to MVOE at $5 \%$ confidence level with an adjusted $\mathrm{R}^{2}$ of .9448. The explanatory power is slightly higher than pool sample but slightly lower that cost model sample. A conclusion can be made that BVOE of cost model sample is value relevant. This result support the study done by Landsman (1986) that BVOE of equity was value relevance that is able to explain the variation in MVOE. Second regression model that separated BVOE into BVENOIP and IP show that BVENOIP and IP are significant at 95\% confidence level with an explanatory power of $94.37 \%$ (Adj. $\mathrm{R}^{2}=.9437$ ). It indicates even though BVOE was separated into BVENOIP and IP, they are still significant and able to explain the variation in MVOE separately however with a slightly lower explanatory power. It is concluded that IP of fair value model sample is value relevant.

Table 7. Relationship of BVOE, BVENOIP, IP and IP towards MVOE (Fair value sample)

\begin{tabular}{lrrr}
\hline & $\begin{array}{r}\text { Model 1 } \\
\text { Coefficient (Sig) }\end{array}$ & $\begin{array}{r}\text { Model 2 } \\
\text { Coefficient (Sig) }\end{array}$ & $\begin{array}{r}\text { Model 3 } \\
\text { Coefficient (Sig) }\end{array}$ \\
\hline Constant & $-2.95(.001)$ & $-2.95(.001)$ & $-8.54(.000)$ \\
BVOE & $4.54(.000)$ & & $.5032(.307)$ \\
BVENOIP & & $4.54(.000)$ & \\
IP & & $4.67(.002)$ & $30.42(.000)$ \\
NP & & & 54 \\
N & 54 & 54 & 7639.8 \\
F Stat & $908.0(.000)$ & $445.3(.000)$ & .9967 \\
R $^{2}$ & .9458 & .9458 & .9965 \\
Adj. R $^{2}$ & .9448 & .9437 & \\
\hline Two-tailed regression models were utilised. & &
\end{tabular}

Regression using model 3 indicates that only NP is significantly related to MVOE. BVOE is not significant. Surprisingly NP alone can explain $99.65 \%$ of the variation in MVOE at $95 \%$ confidence level leaving BVOE irrelevant in explaining the variation of MVOE of fair value model sample. It is important to note that NP in this model is representing the fair value gain or loss on investment property owned by the firms. It has an incremental value relevance of 5.17\% (.9965 - .9448) from Model 1. Indirectly, fair value gain or loss of investment property are value relevant.

\subsection{Discussions}

Model 1 show that BVOE is value relevant regardless of investment property valuation model selected. This is in line with the result of prior study Landsman (1986). Model 2 show that BVENOIP and IP are value relevant regardless whether cost model or fair value model was selected. The results of Model 2 able to accept $\mathrm{H}_{\mathrm{A}} 1, \mathrm{H}_{\mathrm{A}} 2$ and $\mathrm{H}_{\mathrm{A}} 3$ that investment property are value relevant regardless of the valuation model. However, BVOA, BVENOIP and IP of cost model show higher explanation for MVOA as compared to fair value model. This support the result of Acaranupong (2017) and Lawrence and Curto (2007) whereby cost model was more value relevant. Model 3 show that NP of fair value model is more value relevant than NP of cost model. The result of current study is following the results of So and Smith (2009).

\section{Conclusion}

The purposes of the study are firstly to investigate the selection of valuation models for investment properties of Malaysian listed firms and its determinants. Secondly, the study intends to investigate the value relevance of investment properties reported using cost model and fair value model in the respective statement of financial position and statement of profit or loss. With regards to statement of financial position, it is represented by book value of equity (net asset) and book value of investment property. Statement of profit or loss is represented by net profit. 
First of all, the selection of model for valuation of investment properties in Malaysia was determined by firm growth and not the size, the profitability of the leverage of the firm. Fifty percent of companies selected cost model and the rest selected fair value model. Majority of small companies prefer cost model whereas majority of large company prefer the fair value model.

Secondly, based on Landsman (1986) models, investment property are value relevant and significantly explain the variation in market value of equity of the pool, cost model sample as well as fair value model sample with investment property valued using cost model is more value relevant.

Thirdly, based on Ohlson model, NP which include depreciation expenses (under cost model) and fair value gain or losses (under the fair value model) are value relevant and significant in explaining the variation in market value of equity in pool, cost model and fair value model samples with NP that include fair value gain or losses valued using fair value model is more value relevant than NP that include depreciation charge under cost model.

Finally, the result provides useful insight to standard setters about the effect of selection of fair value model and cost model towards share market value. Standard setters, researchers and academics would benefit from this as prior research in Malaysia suggests that investment properties (in general) are not value relevant even though investment properties of property companies are value relevant. The reults provides the latest evidence on selection, determinants and value relevance of investment property in Malaysia after the adoption of MFRS 140 - Investment Property.

\section{Acknowledgements}

The authors would like to thank Universiti Teknologi MARA Johore Branch for providing financial assistance under the Geran Berstari Scheme (GBest 2019).

\section{References}

Abdul Jabar, J., \& Mohamed, A. (2015). The Practices of Fair Value Reporting on Investment Property in Malaysia. Proceedings of the International Conference on Accounting Studies (ICAS) 2015, pp. 17-23.

Acaranupong, K. (2017). Accounting Practices and Value Relevance of investment Property: Evidence from Firms Listed on the Stock Exchange of Thailand. Asian Journal of Business and Accounting, 10(2), 1-41.

Alhaj Ahmad, F. B., \& Aladwan, M. S. (2015). The Effect of Fair Value Accounting on Jordanian Investment Properties An Empirical Study on Jordanian Listed Real Estate Companies. International Journal of Financial Research, 6(4), 99-113.

Alhusaini, W., \& Elshamy, M. (2016). Accounting For Property Investment: An Examination of the Value Relevance of Unrealised Gains and Losses Recognised Under IAS 40. International Journal of Accounting and Finance, 6(2), 79-87.

Al-Khadash, H. A., \& Khasawneh, A. Y. (2014). The Effects of the Fair Value Option under IAS 40 on the Volatility of Earnings. Journal of Applied Finance \& Banking, 4(5), 95-113.

Ball, R. (2006). International Financial reporting Standards (IFRS); pros and cons for investors. Accounting and Business Research, 36(S1), 5-27.

Elsiefy, E., \& ElGammal, W. (2017). The Effect of Using Fair Value Accounting on Fundamental Analysis: Some Evidence From the Emerging Economies. The Journal of Developing Areas, 51(3), 103-121.

Gopalakrishnan, V., \& Sugrue, T. F. (1993). An Empirical Investigation of Stock Market Valuation of Corporate Projected Pension Liabilities. Journal of Business Finance, 20(5), 711-724.

Ibrahim, M. K., Danila, R., Yusoff, H., \& Yatim, N. (2002). Market Value and Balance Sheet Numbers: Evidence from Malaysia. Asian Review of Accounting, 10(1), 77-88.

Isa, M. A. (2014). Determinants of accounting choice of non-current assets at IFRS first adoption among Nigerian firms. International Conference of Accounting Studies, Kuala Lumpur, Malaysia.

Ishak, H. S., Saringat, S. M., Ibrahim, M. K., \& El Shahat, M. F. (2011). Value Relevance of Fair Value Model on Accounting for Investment Property (FRS 140). 3rd International Conference on Business and Economic Research (3rd Icber 2012).

Israeli, D. (2015). Recognition versus disclosure: evidence from fair value of investment property. Review of Account Studies, 20, 1457-1503.

Jennings, R., Robinson, J., Thomson, R. B., \& Duvall, L. (1996). The Relations Between Accounting Goodwill 
Numbers and Equity Values. Journal of Business Finance and Accounting, 23(4), 513-533.

Kane, E., \& Unal, H. (1990). Modeling Structural and Temporal Variation in the Market's Valuation of Banking Firms. Journal of Finance, 45(1), 113-36.

Landsman, W. R. (1986). An Empirical Investigation of Pension Fund Property Rights. The Accounting Review, 61(4), 662-691.

Landsman, W. R. (2007). Is Fair Value Accounting Information Relevant and Reliable? Evidence from Capital Market Research. Accounting and Business Research, 37(sup1), 19-30.

Lourenço, I. C., \& Curto, J. D. (2007). The Value Relevance of Investment Property Fair Values. European Accounting Association Congress (Lisbon).

McCarthy, M. G., \& Schneider, D. K. (1995). Market Perception of Goodwill: Some Empirical Evidence. Accounting and Business Research, 26(1), 69-81.

Muller III, K. A., Riedl, E. J., \& Sellhorn, T. (2008). Choosing Historical Cost versus Fair Value and the Consequences of Mandatory IFRS Adoption in the EU. Unveröffentlichtes Arbeitpapier, Pennsylvania State University/Harvard Business School/Ruhr-Universität Bochum.

Nellessen, T., \& Zuelch, H. (2011). The reliability of investment property fair values under IFRS. Journal of Property Investment \& Finance, 29(1), 59-73.

Ohlson, J. A. (1995). Earnings, Book Values, and Dividends in Equity Valuation. Contemporary Accounting Research, 11(2), 661-687.

Pfeiffer, R. J. (1998). Market Value and Accounting Implications of Off-Balance-Sheet Items. Journal of Accounting and Public Policy, 17(3), 185-207.

Sekaran, U. (2006). Research methodology for business. New York: John Wiley and sons Inc.

Selas, D. N. G. D. C. (2009). The Value Relevance of Investment Property Fair Value Portuguese Case. Unpublished Dissertation, Universidade Nova De Lisbo, Portugal.

Shevlin. (1991). The Valuation of R\&D Firms with R\&D Limited Partnerships. The Accounting Review, 66(1), 1-21.

So, S., \& Smith, M. (2009). Value-Relevance of Presenting Changes in Fair Value of Investment Properties in The Income Statement: Evidence from Hong Kong. Journal of Accounting and Business Research, 39(2), 103-118.

Tabachnick, B. G., \& Fidell, L. S. (2013). Using Multivariate Statistics (6th ed.). Boston: Pearson Education.

Taplin, R., Yuan, W., \& Brown, A. (2014). The Use of Fair Value and Historical Cost Accounting for Investment Properties in China. Australasian Accounting, Business and Finance Journal, 8(1), 101-113.

Wahyuni, E. T., Soepriyanto, G., Avianti, I., \& Naulibasa, W. P. (2019). Why Companies Choose The Cost Model Over Fair Value For Investment Property? Exploratory Study on Indonesian Listed Companies. International Journal of Business and Society, 20(1), 161-176.

Weijun, N. (2007). The Effect of Fair Value Accounting in HKAS 40 on Real estate companies Listed in Hong Kong. Hong Kong Baptist University.

Yamamoto, T. (2014). Fair Value of Investment Property and Independent Appraisers: The Experience in the UK and Japan. The Appraisal Journal, 82(2), 138-154.

Zi, T. M., Hassan, M. S., \& Embong, Z. (2014). Value Relevance of Investment Properties' Fair Value and Board Characteristics in Malaysian Real Estate Investment Trusts. Asian Journal of Accounting and Governance, 5, $1-13$. 